LET: Linguistics, Literature and English Teaching Journal

||Volume||11||Issue||1||Pages||42-60||2021\|

|P-ISSN: 20869606; E-ISSN: 25492454|

Available online at: http://jurnal.uin-antasari.ac.id/index.php

\title{
MAXIMIZING THE USE OF WHATSAPP IN ENGLISH REMOTE LEARNING TO PROMOTE STUDENTS' ENGAGEMENT AT MADURA
}

\author{
Eva Nikmatul Rabbianty \\ eva@iainmadura.ac.id
}

\author{
Abd Ghofur \\ abd.ghofur@iainmadura.ac.id
}

Abdul Wafi

abdulwafi@iainmadura.ac.id

State Islamic Institute of Madura, Indonesia

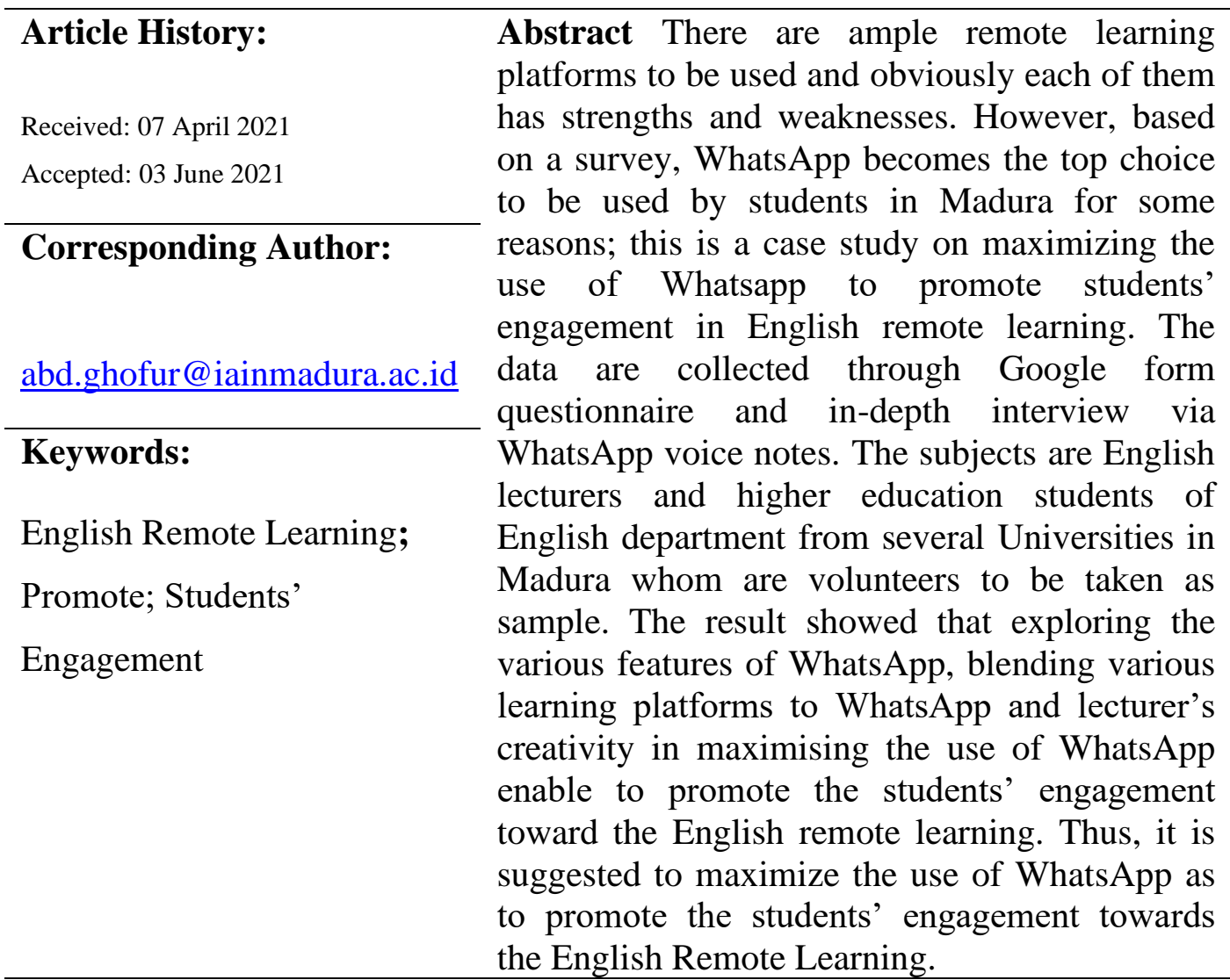

Eva Nikmatul Rabbianty

LET: Linguistics, Literature and Language Teaching Journal Vol. 11 No. 12021 


\section{INTRODUCTION}

During the pandemic of COVID-19, the disruption is getting clearer in multifaceted aspects including in the education sector. Schools are no longer allowed to conduct the regular face-to-face learning for the sake of safety and for stopping the spread of COVID-19. Students and teachers are working at home the best they can do through the use of online learning or remote learning. It is a must or even a perforce for everyone to get accustomed to having online or remote learning as to continue the education. Online education is a pedagogical transformation from conventional to modern teaching-learning approach from classroom to zoom, from personal to interactive and from seminars to webinars. Thus, conducting remote learning is taken as emergency due to the outbreak of Covid-19.

Remote or distance education is used to describe education provided through print, audio, video (live or pre-recorded) and/or computer technology to distant or remote locations. (Owens et al., 2009). Remote learning is described as a rapidly expanding environment that enables users to work flexibly outside of time and location constraints (Gilbert, 2015). Remote learning aims to replicate the classroom experience while the student learns via the machine by logging in at scheduled times to view lectures or engage in group learning activities in the virtual classroom environment. It is learning that takes place partly or completely on the Internet. (Means et al., 2010). The learning which is conducted by combining online through internet connection and a face-to-face or classroom session is called as blended or hybrid learning (Bach et al., 2007) and (Watson, 2008). Viewing from an educational perspective, blended learning refers to the integration of online teaching activities with traditional face-to-face class activities in a planned and systematic manner (Chowdhury, 2019).

Meanwhile, the type of communication modes in the online learning is either synchronous or asynchronous. Asynchronous e-learning, commonly facilitated by media such as e-mail and discussion boards, supports work relations among learners and with teachers, even when participants cannot be online at the 
same time. Asynchronous e-learning makes it possible for learners to log on to an e-learning environment at any time and download documents or send messages to teachers or peers. In order to prepare the learning materials, teachers are versatile and encourage students to juggle the demands of home and study. Since it works best in digital formats, in the set time, teachers do not have to deliver the content. Asynchronous learning provides more space for educators and students to breathe (Daniel, 2020). Synchronous e-learning has the ability to assist e-learners in the growth of learning networks, also assisted by media such as video conferencing and chat. Synchronous sessions make e-learners feel more like participants than isolated participants (Hrastinski, 2008).

The effectiveness of remote learning is still debatable from day to day. Researchers make endeavour to provide the remote learning as effective as possible. One of its effectiveness is enabling to promote students' engagement in the learning. The term 'student engagement' refers in general terms to the effort and commitment that students give to their learning, although NSSE specifically considers ways in which active and collaborative learning, the level of academic challenge, interaction between students and faculty, and a supportive campus environment all influence such engagement(Kahn et al., 2017). There are three forms of engagement: (1) cognitive or intellectual engagement (investment)investment of effort and self-regulation by the individual focusing on academics 'deep, intellectual learning and intellectual growth, as evidenced by motivation, attitude, commitment, and self-regulation (2) socio-emotional engagement (reaction)-the affective reaction of the students to the student (2) Socio-emotional engagement (reaction)-the affective response of students to learning, such as happy, bored, excited and the like, and (3) behavioural engagement (participation)-students take part in learning activities (Sesmiyanti, 2016).

Experts offer many tips on how to achieve the most successful remote learning experience. To make remote learning more successful, Wexler offers seven tips: (1) get students into the habit of participating by giving them incentive to show up or complete tasks and making the goals and expectations crystal clear. 
(2) concentrating on content, not knowing skills (3) keeping it simple; preventing the use of too many different network apps (4) linking new content to old content and offering an example (5) In short doses, dole out new information (6) Make online learning as engaging as possible (7) combine synchronous and asynchronous learning with new knowledge in small doses (Wexler, 2020).

Remote learning uses e-learning platforms. Bri,__García,__Coll,_\&_Lloreet, (2009) described e-learning platforms as the environment for hardware and software designed to automate and manage academic training activities for development. Management and registration of users, tools and training programs, access supervision, control and monitoring of the learning process, assessment, knowledge and management of communication facilities are the main functions. There are ample e-learning platforms to be used. Each of them has their strengths and weaknesses. So, it is advisable to know the basic characteristics of the platforms. In Fernandez et.al, Bates notes that any platform should have four fundamental and important characteristics; (1) interactivity; ensuring that the individual using the platform is aware of playing the leading role in his or her training; (2) flexibility; the collection of functionalities that enable the eLearning framework to be easily adapted to the organization that wishes to incorporate it. (3) scalability; enabling the platform to operate similarly for a small or large number of users (4) standardization; the ability to use courses conducted by a third party; courses are open to the company that developed them and those that comply with the standard (Fernandez et al., 2011).

Various e-learning applications have been made to meet the essential characteristics. They are Google classroom, Moodle, Schoology, Edmodo, Zoom, WhatsApp and so forth. Each of them provides benefits as well as barriers. However, due to its simplicity, familiarity and lowcost consumption, someone prefers to use one of those apps moreover during the outbreak of COVID-19. According to a survey conducted by Wahsun, (2020) to teachers around East Java, the result showed that WhatsApp becomes the trend or top choice learning platform during the pandemic. Of 450 respondents (teachers), 390 of them 
$(28,19 \%)$ In addition, in Madura (a small island located in the northern of Surabaya, East java), the use of WhatsApp also becomes a trend. Based on the researcher's survey to 33 college students and 11 lecturers from 7 different colleges in Madura, it was also found that they prefer to use WhatsApp in their learning during the pandemic.

Created in 2009, WhatsApp is one of the most widely used apps for social networks by learners in many developing countries (Mwakapina, Mhandeni, \& Nyinondi, 2016) and is one of the most popular apps people use for any reason ranging from social exchanges to video or photo sharing (Yavuz, 2017). There are numerous studies in the area of e-learning related to the use of Whatsapp. A research on the responses of students to the use of WhatsApp in learning was conducted by Wijaya (2018). The outcome showed that even though some difficulties existed, most students enjoyed learning. The biggest disruption was the internet connection that had to be provided through the efforts of the students themselves. The different characteristics have made it easy for students to learn that English skills can be enhanced. Barhoumi conducted a study on the effectiveness of Whatsapp. The result showed that, when used in a blended course approach, Whatsapp is a good tool for mobile learning. This has contributed to the achievement and attitude of students towards mobile learning and teaching (Barhoumi, 2015). Guler, through his analysis, WhatsApp was found to be a valid tool for peer review anonymously. (Guler, 2016). In addition, WhatsApp was found as a tool that gave strong effect to students' achievement (Nitza \& Roman, 2016). Related to the use of WhatsApp in enhancing online learning, Ngalomba shared his best practice in teaching by using WhatsApp. He considered that WhatsApp is under-utilised and which can provide new impetus for digital education. WhatsApp is a primarily a communication application but shares a number of features with social media applications. It is cost-effective and easy to use, giving it competitive advantage. However, as a popular software application used to track online training activities, social media channels such as WhatsApp 
should be incorporated into a learning management system (LMS) to make it more advanced (Ngalomba, 2020).

Yavuz performed a case study on the use of WhatsApp in the EFL sense and its effect on student performance. The result showed that collaborative applications such as WhatsApp Messenger improve the performance of the students' homogeneity. It suggested that it could work better to combine traditional and technology-supported approaches (Yavuz, 2017). In this study, the researcher would like investigate the use of WhatsApp maximally in the remote learning enables to promote the students' engagement. Thus, the researcher would like to address some research questions of (1) What features are there in WhatsApp that can be used to promote students' engagement? (2) What remote learning platforms can be blended to Whatsapp in promoting students' engagement? (3) How WhatsApp can promote students' engagement in English remote learning.

\section{METHOD}

\section{Research design}

This study belongs to a case study with qualitative research design. The term case-study is often used to describe a study involving data from a real setting (in our case, often a practice setting) and is seen as similar to an observational study involving only one or very few events(Blessing \& Chakrabarti, 2009). Meanwhile, Qualitative study is defined as a systematic empirical investigation that seeks to construct a holistic, primarily narrative, explanation to inform the understanding of a social or cultural phenomenon by the researcher. Based on a mixture of observations, interviews, and document reviews, qualitative research was carried out. (Astalin, 2013).

\section{Research site and participants}

The setting is in Madura - an island, located in the north of Surabaya, East Java Indonesia. It consists of four regencies namely Bangkalan, Sampang, Pamekasan and Sumenep. There are 7 universities to be sample of survey; they 
are Universitas Trunojoyo Madura, Insitut Agama Islam Negeri Madura, Universitas Islam Madura, Institut Agama Islam Al-Khairat Pamekasan, Institut Kariman Wirayudha Sumenep, Universitas Wiraraja Sumenep, Institut ilmu Keislaman Annuqayah (INSTIKA) Guluk-guluk Sumenep. The subjects are 33 college students and 11 English lecturers from those universities. The data were collected through Questionnaire via Google form and interview via WhatsApp voice note.

\section{Data collection and analysis}

The collection of the data is conducted through questionnaire via Google form and interview via WhatsApp. The questionnaire is distributed to students and lecturers via Google form and they are in volunteer to fill the form of the questionnaire. The questionnaire for the students consists of six questions. The first question is yes/no question asking whether they use WhatsApp for their social media. The second is also yes/no question asking whether they more frequently use whatsApp in their daily life (for social media or online learning). The third is asking whether they prefer if their lecturer uses WhatsApp in the learning compared to other applications or platform. The fourth question is related to the third question, asking the reason why they prefer it. The fifth question is asking whether the use of WhatsApp enable to make them easier and more actively engaged in the remote learning. The last question is asking their suggestion for their lecturer in the case of maximizing the English learning by using WhatsApp to be more interesting and effective.

The questionnaire for lecturers covers four questions. The first question is asking whether they prefer using WhatsApp in their learning better than using other applications or platforms. The second question is asking their opinion on the strengths of using WhatsApp in the learning. The third question is asking their opinion on the weaknesses of using WhatsApp in the learning. The fourth question is asking their idea on how to maximize the use of WhatsApp to be more effective and to make students more engaged in the learning. 
The interview is conducted to the lecturer only since it is to investigate their experience in teaching and their opinion on creativity in blending various learning platforms. There are four questions to ask. The first is asking whether they are teaching by using WhatsApp. The second question is asking their difficulties in using WhatsApp in their English learning. The third is asking their solution to handle those difficulties. The fourth question is asking their opinion on lecturer's creativity in blending various learning platforms and applications to WhatsApp enable to make the English remote learning become more interesting and more effective in promoting students' engagement toward the learning.

\section{FINDINGS AND DISCUSSIONS}

\section{Findings}

The data are collected through questionnaire via Google form to students and to lecturers and through interview via WhatsApp. The findings from the students' questionnaire are as follow: the first question was asking whether they use WhatsApp for their social media and it was that all students (100\%) use WhatsApp for their social media. The second question was asking they more frequently use whatsApp in their daily life (for social media or online learning) and it was found that $33(100 \%)$ students answered 'yes'. The third question was asking whether they prefer if their lecturer uses WhatsApp in the learning compared to other applications or platform and it was found that $24(72,7 \%)$ students answered 'yes' and $9(27,3 \%)$ answered 'no' which is meant that they do not prefer if their lecturer uses WhatsApp in the learning.

The fourth question is a short-answer question asking the reason of question number three. The answer varied. For the students who answer "yes", they proposed their reasons that the use of WhatsApp is simple, efficient and easy to apply. Besides, it is cheap data consumption even sometimes it is free internet data. WhatsApp is a popular application that everyone has and it is effective to be used for remote learning since it has complete feature that needn't to install another application such as ZOOM which makes the internal phone memory 
becomes decreased or low. Meanwhile, the reasons from the students who answer 'no' are (a) using WhatsApp distracts the concentration; when online learning occurs, then a text message is coming in. Besides, lecturer does not really know whether his students really pay attention to his explanation. In addition, there will be messed-up messages when some students give their comment. The discussion via WA is not so effective since it is only in Group and sometimes students only fill the attendance list; different from $\mathrm{ZOOM}$ where it is video conference that the lecturer can monitor every student.

The fifth question is a yes/no question asking whether the use of WhatsApp enable to make them easier and more actively engaged in the remote learning. From the students' answer, it was found that $28(84.8 \%)$ students answered 'yes' and $5(15.2 \%)$ students answered 'no'. the sixth question is a longanswer question asking their suggestion for their lecturer in the case of maximizing the English learning by using WhatsApp to be more interesting and effective. From their response, it was found that various answers as follow: (a) use more audio (e.g. voice message) to train students' listening skill (b) use WA for classroom-group only to share info, material and tasks. Ask students to make video about the topic given and upload it in Instagram or youtube (live) (c) send the learning material in advance that the students make preparation for understanding it. Don't just share PPT or doc. File, but use video call/conference when lecturer conducts teaching (d) to avoid boredom, lecturer should make interesting and interactive learning material such as animated slides completed with audio and moving pictures. (e) Attendance list should be in the end of the session to ensure the students join it. Answer all questions from students; no choosing as to avoid jealousy. Conduct the learning in the morning or afternoon. (f) try to find and use other strategies instead of having WAG only (g) in speaking class, maximize the use of Voice note. In discussion session, better to use personal chat than group chat to avoid the piled messages (h) make and explain the learning material simple and short (i) have meticulous control and supervision for the students' engagement and active involvement (j) Avoid giving assignments 
too much (k) use various and different techniques in each meeting (l) make interesting video explaining the topic then upload it to Youtube (Lecturer's channel); share the link via WAG and ask the students to watch; with that, students might watch and watch again to get deeper understanding of the topic being explained $(\mathrm{m})$ make games by utilizing anything from other platforms.

From the lecturers' response to questionnaire distributed via Google form, it results findings as follow: the first question was asking whether they prefer using WhatsApp in their learning better than using other applications or platforms. It was found that $9(82 \%)$ lecturers answered 'yes' which meant they prefer using WhatsApp in their learning meanwhile the rest 2 (18\%) answered 'no' which meant that they prefer using other applications or platform for their learning.

The second question was asking their opinions related to the strengths of using WhatsApp in the learning. From their responses, it was found that using WhatsApp is simple, familiar and affordable. Using whatsApp is cheap and economical as well as practical and the network is stable. Everyone has it because it is easy to apply. Meanwhile, the third question was asking the weaknesses of using WhatsApp in the learning. Their responses varied. They said that the weaknesses of using WhatsApp were no 'auto correction' feature and messages or chats were overlapping. It needs to link to another app to manage the students' attendance. Using whatsApp was unable to see which student is really joining the learning. There was limited number in video and the network would be unstable if having video-call. It also needs more space if everyone wants to share. There were more passive students that the active (silent) ones. Since WhatsApp is used for social media, it resulted that the storage is easy to be full due to too many files coming.

The fourth question was asking their suggestion on how to maximize the use of WhatsApp to promote students' engagement in the remote learning. Their suggestions varied. They suggested that controlling and managing the students' attendance by making strict rules and technical guides about do's and don't's; ensure that the students engage in the learning by making it as the learning 
parameter. There should be effective discussion method by using voice note (as faster response), emoticon (expressing feeling/idea through picture) and text message to improve writing; maximize the voice recorder. Another suggestion is to make WAG as mini library for learning materials given or to be given. Send the PPT to students and ask them to read and review and share it through video or voice notes. Another suggestion is to have WhatsApp be blended or integrated to other learning applications or platforms.

Another way to collect the data is by having interview to four volunteer lecturers via WhatsApp. There were four questions to ask. The first question was asking whether they teach English in remote learning by using WhatsApp. It was found that all of them answered 'yes' which meant they use WhatsApp in their English remote learning. The second question was asking their difficulties or the problems of using WhatsApp in their English remote learning. It was found that the problems encountered were overlapping chatting, being unable to control students and having unstable internet connection. They also feel unskillful in operating all WhatsApp features. They also got difficulties in handling or managing the record of students' assignments.

The third question was asking their possible solutions to handle those difficulties. From their responses, it was found that to handle the overlapping chatting, the lecturer should mute the chat that only admin can share or give response. The possible solution to control students was by giving them sudden question or quiz that they could focus and pay attention to the learning. Meanwhile, to handle the unstable internet connection, it should move to another place to find better connection. Related to their unskillfulness in operating WhatsApp features, the possible solution was asking the co-worker and or browsing in Google to be more skilful. For handling or managing the record of students' assignments, the possible solution was by integrating it to other apps such as Google classroom, Youtube, e-mail and the like.

The fourth question was asking their opinions on the agreement or disagreement of the lecturer's creativity in blending various learning platforms 
and applications to WhatsApp enable to make the English remote learning become more interesting and more effective in promoting students' engagement toward the learning. From their response, it was found that all of them agreed with it with several reasons such as to avoid boredom, to encourage students' active involvement, to avoid monotonous learning activities. Another reason was because the creative lecturers or facilitators would develop their students' creativity.

\section{Discussion}

Features in WhatsApp to promote students' engagement

Using WhatsApp in English remote learning is getting more popular among us since it is simple and easy to apply. Its familiar features such as text messaging, video call, sending files and particularly WAG (WhatsApp) are the features. According to Bere in Gon, the following interactive features are supported by WhatsApp Messenger: (a) Multimedia: enabling users to share videos, text messages, images, and voice notes. (b) Community Chat: contact help for up to 50 members of the group. (c) Unlimited Messaging: Users are free to send and share messages. (d) To ensure uninterrupted data transfer across networks, the program uses 3G/4 G EDGE internet data plan or Wi-Fi. (e) Crossplatform engagement: users can connect with other users on various devices, such as Android phones, iPhones, and can communicate with each other through different media, such as text, photographs, and the like. (f) Offline Messaging: When the system is off or outside the coverage area, messages are saved automatically. (g) No fees: there are no fees for the use of WhatsApp because it uses the same Internet service plan that is used for email or web browsing. (h) Name of Pins and Users: WhatsApp users do not need to remember passwords or usernames as they operate through phone numbers and integrate address books with users. (Gon \& Rawekar, 2017)

Of those features, as the finding of this study found that WAG is the most used feature by lecturer and students in their learning. Via WAG, lecturer sends 
PPT files and asks students to review it, uses voice messages to train students' listening skill, uses text messages to improve students' writing skill. However, those features are not really in maximum use as the effort to promote students' engagement.

There are a lot of activities to conduct by using the features in WhatsApp to be applied in the English remote learning. Haynes proposed 25 ideas for using WhatsApp with English language students by using text, photo, video, audio and emoticons. Each of those features can stand alone or can be blended with another feature. Through text messaging, lecturer can do teaching activities such as gap-fill, incorrect sentences, odd-one-out. Through audio (voice note), lecturer can do distance-interview, audio-diary. Through video, lecturer can do 30 -second presentation and tour guide. Lecturer can blend the use of emoticon with text messaging such as emoticon race, emoticon stories. Lecturer can also use photo blended with text messaging such as photo story, photo diary, feeling illustration and describing a process (Haynes, 2016).

In promoting the students' engagement, lecturers can see the level of their students' engagement toward the learning. Shclechty divided the commitment into five levels; they are (1) Authentic Engagement-students are involved in work that has a specific significance and immediate importance to them (2) Ritual Compliance-the work has little or no immediate significance to students, but there are extrinsic value outcomes that keep them engaged (3) Passive Compliancestudents see little to no meaning in the assigned work, but invest little to no meaning in the assigned work. (4) Retreatism-students are disengaged from assigned work and make no effort to comply, but are not disruptive to others' learning (5) Rebellion-students fail to conduct the assigned mission, act disruptive, and try to replace alternative activities (Schlechty, 2011). So, by maximizing the use of the features in WhatsApp, the students' engagement can be promoted from level 5 to level 4 , from level 4 to level 3 to 2 and finally to 1 as authentic engagement. 
Blending various digital learning applications to WhatsApp

The era 4.0 brings technology in extremely advance. Through internet connection, everything is conducted via online. Various digital learning devices, platforms, applications are made to make life easy, simple and fast. Google classroom, edmodo, Zoom, Google meet, Facebook, Twitter, Instagram, Telegram, Youtube and so forth. Google, as search engine, makes us easy to find out what we want such as books, pictures, journal articles, audio files and so on. Through Youtube, we can enjoy various videos all around the world. We can make online survey through Google form. Everything is available and able to be instantly accessed within seconds just by clicking the button. However, each platform or application has its strengths and weaknesses such as Zoom which its superiority is for video conference with a large number of people around the world;

WhatsApp, as social base application, is used for learning. Of its ample strengths, there are weaknesses as well. From the finding, it was found that the weaknesses of WhatsApp are unable to provide interactive discussion for a large number of people like Zoom has. WhatsApp video call is only limited for 8 people. Using WhatsApp in the learning is quite difficult to control the student of which student is fully engaged in the learning activities; who is active and who is passive. It is different from Google classroom which is specifically designed for learning activities that enables the teacher to fully control the learning activities. It is also rather complicated to manage the students' attendance like Google form or android applications such as Absensi siswa, Jibble, attendzone, KitaSchool and so forth. Since each application has its strengths and weaknesses, it is suggested to blend and integrate one application to another one to complete each other and to make the learning activities become more effective, interesting and interactive. By blending all features in whatsApp and integrating them to other digital learning applications, each student can write text, see the messages, watch videos, listen to audio and voice notes and the like and that the learning will become more effective. People can remember just 10 percent of what they read, 20 percent of what they hear, 30 percent of what they see, and 50 percent of what they hear and 
see, according to Dale's Experience Cone. The percentage can be even greater than 50 percent with the emergence of certain innovations that combine images, texts and audio all in one (Davis \& Summers, 2015) and (James M., 2002).

\section{Lecturer's creativity in maximizing the use of WhatsApp}

Creativity is a quality that expresses itself in many different ways, and that is one of the reasons why it has been so hard to describe. However, Creativity was described by Franken as the propensity to produce or recognize ideas, alternatives or possibilities that may be helpful in solving problems, interacting with others, and entertaining ourselves and others (Franken, 1994). In an orgy of totally free self-expression, creativity is widely thought to be about letting the imagination loose. Creativity is an individual thinking process related to an activity (Maley \& Peachey, 2015). Anything can be creative - creativity is a perspective that is brought to an activity Creativity is a part of $21^{\text {st }}$ century skill to master by students.

Lecturer, with his authority, is as the person who is in charge in providing and managing the learning activities. A creative lecturer is one who, while reinforcing creative practices, advocates rational risks and unexpected circumstances. (Morais \& Azevedo, 2011). Lecturer's creativity is indeed significant to maximize the use of WhatsApp. Based on the result of questionnaire and interview with lecturers, it was found some ideas on how to maximize the use of WhatsApp namely making WAG as mini library, maximizing the use of voice note and integrating or blending WA with other digital applications or platforms. In addition, lecturer can also have effective discussion method by using voice note (as faster response), emoticon (expressing feeling/idea through picture), text message to improve writing. If then the lecturer is not skillful or creative enough to maximize the use of WA, it is suggested to discuss and share it to co-workers, joining workshop and seminar related to how to be creative lecturer or just do Googling to get various inspiration or ideas. 
Meanwhile, from the result of students' questionnaire, they suggest that to maximize the use of WhatsApp, the lecturers should provide fun games or interactive quiz by integrating it with other platforms such as Kahoot.

\section{CONCLUSIONS AND SUGGESTIONS}

Technology is reaching its awesome advance. Various digital devices and applications have been created. However, in the learning activities, its use would not be maximum due to three main obstacles; they are (a) the availability technology and internet connection, (b) teacher techno-phobia and (c) the insufficient knowledge on how to use it maximally for learning purposes.

WhatsApp is social media platform but widely used for remote learning particularly during Covid-19 pandemic due to its simplicity, low-cost internet data consumption and familiarity. There are a lot of features there such as text messaging, photo, sending files, video call and the like. However, those features are not in maximum use. The reason might be in the case of lack of creativity in utilizing and exploring those features. In the learning activities, lecturers are supposed to increase their creativity in using those features through searching in Google or You-tube to find out what ideas and what possible activities to be conducted by using the features in WhatsApp and that the use will be maximum in promoting students' engagement toward the English remote learning.

\section{REFERENCES}

Astalin, P. K. (2013). Qualitative Research Designs: A Conceptual Framework. International Journal Of Social Sciences \& Interdisciplinary Research, 2(1), 118-124.

Bach, S., Haynes, P., \& Lewis Smith, J. (2007). Online Learning And Teaching In Higher Education (1 ed). McGraw Hill Open University Press. https://books.google.co.id/books?id=oH9edLz16UoC\&printsec=frontcover $\& \mathrm{hl}=\mathrm{id} \&$ source=gbs_ge_summary_r $\& \mathrm{cad}=0 \# \mathrm{v}=$ onepage $\& \mathrm{q} \& \mathrm{f}=\mathrm{false}$

Barhoumi, C. (2015). The Effectiveness of WhatsApp Mobile Learning Activities Guided by Activity Theory on Students' Knowledge Management. 18.

Blessing, L. T. M., \& Chakrabarti, A. (2009). DRM, a Design Research Methodology. London. 
Bri, D., García, M., Coll, H., \& Lloret, J. (2009). A Study of Virtual Learning Environments. 6(1), 11.

Chowdhury, F. (2019). Blended learning: How to flip the classroom at HEIs in Bangladesh? Journal of Research in Innovative Teaching \& Learning, ahead-of-print(ahead-of-print). $\quad$ https://doi.org/10.1108/JRIT-12-20180030

Daniel, S. J. (2020). Education and the COVID-19 pandemic. PROSPECTS. https://doi.org/10.1007/s11125-020-09464-3

Davis, B., \& Summers, M. (2015). Applying Dale's Cone of Experience to increase learning and retention: A study of student learning in a foundational leadership course. QScience Proceedings, 2015(4), 6. https://doi.org/10.5339/qproc.2015.elc2014.6

Fernandez, R., Palacios, D., Gill, I., \& Devece, C. (2011). (PDF) Technology platforms in distance learning: Functions, characteristics and selection criteria for use in higher education. ResearchGate. https://www.researchgate.net/publication/290096909_Technology_platfor ms_in_distance_learning_Functions_characteristics_and_selection_criteria _for_use_in_higher_education

Franken, R. E. (1994). Human Motivation (3rd ed.). Pacific Grove, Calif Brooks/Cole Pub. Co.

Gilbert, B. (2015). Online Learning Revealing the Benefits and Challenges. ONLINE LEARNING, 34.

Gon, S., \& Rawekar, A. (2017). Effectivity of E-Learning through Whatsapp as a Teaching Learning Tool. MVP Journal of Medical Sciences, Vol 4(1), 1925, January-June 2017, 4(1). https://doi.org/10.18311/mvpjms/2017/v4i1/8454

Guler, C. (2016). Use of WhatsApp in Higher Education: What's Up With Assessing Peers Anonymously? Educational Computing Research, O(0), 1-18. https://doi.org/10.1177/0735633116667359

Haynes, P. (2016, May). 25 ideas for using WhatsApp with English language students | OUP. Oxford University Press. https://oupeltglobalblog.com/2016/05/17/25-ideas-for-using-whatsappwith-english-language-students/

Hrastinski, S. (2008). Asynchronous and synchronous e-learning. Educause Quarterly, Number 4. https://www.google.com/search?q=Hrastinski\%2C+Stefan.+(2008)+Async hronous+and+synchronous+elearning.+Educause+Quarterly\%3A+Number+4+2008.+P.5152\&oq=Hrastinski\%2C+Stefan.+(2008)+Asynchronous+and+synchronous +e-learning.+Educause+Quarterly\%3A+Number+4+2008.+P.51$52 \&$ aqs $=$ chrome..69i57.4064j0j7\&sourceid $=$ chrome $\&$ ie $=U T F-8$ 
James M., M. (2002). Learning with technology: Evidence that technology can, and does, support learning. https://www.researchgate.net/publication/324845137_Learning_with_tech nology_Evidence_that_technology_can_and_does_support_learning

Kahn, P., Everington, L., Kelm, K., Reid, I., \& Watkins, F. (2017). Understanding student engagement in online learning environments: The role of reflexivity. Educational Technology Research and Development, 65(1), 203-218. https://doi.org/10.1007/s11423-016-9484-z

Maley, A., \& Peachey, N. (2015). Creativity in the English language classroom. British Council.

Means, B., Toyama, Y., Murphy, R., Bakia, M., \& Jones, K. (2010). Evaluation of Evidence-Based Practices in Online Learning: A Meta-Analysis and Review of Online Learning Studies. In US Department of Education. US Department of Education. https://eric.ed.gov/?id=ED505824

Morais, M. F., \& Azevedo, I. (2011). What is a Creative Teacher and What is a Creative Pupil? Perceptions of Teachers. Procedia - Social and Behavioral Sciences, 12, 330-339. https://doi.org/10.1016/j.sbspro.2011.02.042

Ngalomba, S. (2020, April). Using WhatsApp to enhance online learning. https://www.universityworldnews.com/post.php?story=202004211028129 87

Nitza, D., \& Roman, Y. (2016). WhatsApp Messaging: Achievements and Success in Academia. International Journal of Higher Education, 5(4). https://doi.org/10.5430/ijhe.v5n4p255

Owens, J., Hardcastle, L., \& Richardson, B. (2009). Learning From a Distance: The Experience of Remote Students. JOURNAL OF DISTANCE EDUCATION, 23(3), 22.

Schlechty, P. C. (2011). Engaging Students: The Next Level of Working on the Work. John Wiley \& Sons.

Sesmiyanti. (2016). Students' Cognitive Engagement in Learning Process. Journal PROLINGUA, 5(2).

Wahsun, W. (2020). Trend Penggunaan Platfrom Belajar Online oleh Guru di Tengah Pandemi COVID-19. https://www.celotehpendidikan.com/2020/04/trend-penggunaan-platformbelajar.html

Watson, J. (2008). Blending Learning: The Convergence of Online and Face-toFace Education. NACOL (North American for Online Learning), 18.

Wexler, N. (2020). 7 tips to help make remote learning more effective. https://www.forbes.com/sites/nataliewexler/2020/04/08/7-tips-to-helpmake-remote-learning-more-effective/\#638a643b62c3

Eva Nikmatul Rabbianty

LET: Linguistics, Literature and Language Teaching Journal Vol. 11 No. 12021 
Yavuz, F. (2017). Do Smartphone Supr or deter learning: A WhatsApp case study. International Journal of Educational Sciences, 15(3), 408-415. https://doi.org/10.1080/09751122.2016.11890551 